\title{
DAYA TERIMA, KARAKTERISTIK FISIK KIMIA MP- ASI TEPUNG BERAS MERAH DAN TEPUNG KEDELAI PENCEGAHAN STUNTING
}

\author{
Sukmawati ${ }^{1}$, Asmarudin Pakhri ${ }^{2}$, Rezky Ismail ${ }^{2}$ \\ ${ }^{1}$ Jurusan Gizi, Politeknik Kesehatan Kemenkes, Makassar \\ ${ }^{2}$ Alumni Prodi Sarjana Terapan Gizi dan Dietetik Poltekkes Kemenkes Makassar
}

Korespondensi : hj.sukmawaty@yahoo.com 081342712435

\begin{abstract}
Nutritional problems that occur in Indonesia are still not resolved, one of them is stunting. Toddlers are said to be short when z-score body length according to age or height according to age is less than -2 SD (standard deviation) (stunted) and less than -3 SD (severaly stunted).one of the direct causes of child nutrition problems is the inappropriate practice of infant feeding. This study aims to determine the acceptability, physical characteristic and chemical characteristics of the making of local instan complementary milk made from red rice flour and soybean flour. This type of research is an experiment in the field of foof processing carried out in the laboratory. The reseacrh design used was Completely Randomized Design and acceptance test data were analyzed using the ANOVA test and in this study the formula which has the highest acceptability which will be analyzed for its physical and chemical characteristics. The results of this study were the highest formula obtained formula $2(45 \mathrm{gr} ; 35 \mathrm{gr})$ and protein content 13,08 $\mathrm{gr}$, fat 19,23 gr, water content 5,71 $\mathrm{gr}$ and ash content 2,56 $\mathrm{gr}$. The conclusion of this study is that formula 2 obtained the highest value from the acceptance test and then analyzed its physycal and chemical characteristics. It is recommended for future researchers to analyze other nutrients.
\end{abstract}

Keywords: Acceptance, complementary milk Red Rice Flour, Soybean Flour, Stunting

\section{PENDAHULUAN}

Masalah gizi yang terjadi di Indonesia merupakan masalah yang masih belum teratasi sampai sekarang, terutama untuk kelompok rentan gizi. Kelompok rentan gizi merupakan sekelompok orang yang membutuhkan penanganan khusus dalam pemenuhan kebutuhan dasar seperti bayi, balita, ibu hamil, ibu menyusui dan lanjut usia baik dengan fisik normal maupun cacat. Masalah gizi yang masih belum teratasi pada balita antara lain stunting dan gizi kurang (Kementerian Kesehatan RI, 2012).
Berdasarkan hasil pemantauan status gizi Indonesia menunjukkan bahwa anak usia 0-23 bulan terdapat 11,3\% anak yang mengalami gizi kurang dan $3,5 \%$ gizi buruk. Anak sangat pendek 6,9 \% dan pendek $13,2 \%$, serta anak sangat kurus 3,9 $\%$ dan kurus 8,9 \%. Provinsi Sulawesi Selatan menunjukkan bahwa anak usia 023 bulan terdapat $15,2 \%$ anak yang mengalami gizi kurang dan 4,5\% yang gizi buruk. Prevalensi anak sangat pendek $6,1 \%$, dan pendek $15,7 \%$ dan anak sangat kurus 2,4 \% dan yang kurus 9,9\% (Kementerian Kesehatan RI, 2017). 
Stunting atau pendek merupakan kondisi gagal tumbuh pada bayi atau anak yang di akibatkan dari kekurangan gizi kronis terutama dalam 1.000 hari pertama kehidupan sehingga anak terlalu pendek di usianya. Kekurangan gizi terjadi sejak bayi dalam kandungan dan pada masa awal setelah bayi lahir, namun stunting baru terlihat setelah anak berusia dua tahun.

Balita dikatakan pendek ketika nilai zscore panjang badan menurut umur $(\mathrm{PB} / \mathrm{U})$ atau tinggi badan menurut umur (TB/U) kurang dari -2 SD/ (standar deviasi) (stunted) dan kurang dari -3 SD (severely stunted). Balita stunted akan memiliki tingkat kecerdasan tidak maksimal, menjadi lebih rentan terhadap penyakit, dan di masa depan dapat berisiko tinggi mengalami penurunan tingkat produktivitas. Pada akhirnya, secara luas dapat menghambat pertumbuhan ekonomi dan meningkatkan kemiskinan (Ramayulis, dkk, 2018).

Makanan pendamping ASI (MP-ASI) merupakan makanan atau minuman yang mengandung gizi diberikan kepada bayi untuk memenuhi kebutuhan gizinya. Pemberian MP-ASI merupakan proses transisi dari makanan cair (susu) menuju ke makanan yag semi padat. Pengenalan dan pemberian MP-ASI yang cukup dalam hal kualitas dan kuantitas penting untuk pertumbuhan fisik dan perkembangan kecerdasan anak yang bertambah pesat pada periode ini (Departemen Kesehatan RI, 2006).

Makanan tambahan untuk bayi atau biasa dikenal dengan MP-ASI harus menggunakan bahan-bahan yang bermutu, bersih, aman, dan sesuai untuk bayi dan anak usia 6 bulan sampai 24 bulan. Zat gizi yang dikandung MP-ASI bubuk instan harus dapat mendampingi ASI untuk mencukupi gizi pada kelompok umur tersebut. Makanan pendamping ASI bubuk instan dapat dibuat dengan salah satu atau campuran bahan yang merupakan sumber karbohidrat seperti serealia atau umbi- umbian dan bahan sumber protein seperti kacang-kacangan, ikan atau unggas, serta bahan-bahan lainnya (SNI, 2005).

Tepung kedelai merupakan hasil dari bahan baku kedelai yang dijadikan tepung. Proses pembuatannya cukup mudah, dimulai dengan perendaman dan pengupasan kulit biji, pengeringan biji kedelai, penggilingan dan pengayakan. Tepung kedelai secara umum merupakan partikel-partikel kedelai berukuran kecil. Tepung kedelai memiliki banyak manfaat dan mengandung nutrisi tinggi serta baik untuk kesehatan. Contoh produk hasil dari olahan tepung kedelai antara lain untuk membuat biskuit, makanan bayi, dan susu kedelai (Warsino dan Dahana, 2010).

Tepung beras merah adalah salah satu bentuk produk dari beras merah yang setengah jadi yang dapat disimpan lebih lama, mudah dicampur (dibuat komposit), diperkaya zat gizi (difortifikasi), mudah dibentuk dan lebih cepat dimasak sesuai kebutuhan yang serba praktis.

\section{METODE}

\section{Desain, tempat dan waktu}

Jenis penelitian ini adalah eksperimen dibidang pengolahan pangan yang dilaksanakan di laboratorium. Desain penelitian yang digunakan adalah Rancangan Acak Lengkap (RAL). Pembuatan produk MP-ASI, daya terima dan analisis karakteristik fisik telah dilakukan di Laboratorium Teknologi Pangan Poltekkes Makassar Jurusan Gizi dan analisis karakteristik kimia dilaksanakan di Laboratorium Kimia SMK SMTI Makassar. Waktu pelaksanaan penelitian pada bulan Januari - Februari 2019.

\section{Bahan dan alat}

Bahan yang digunakan dalam peneltian ini terdiri atas bahan utama dan bahan pendukung. Bahan utama yaitu beras merah dengan karakteristik bersih dan tidak berbau dan kacang kedelai yang 
baik. Bahan pendukung pembuatan bubuk terdiri atas susu full cream, dam gula pasir yang dibeli dari pasar swalayan, bahan kimia yaitu aquadest serta bahan-bahan untuk analisis fisik produk. Bahan-bahan untuk analisis kimia diantaranya aquades, asam sulfat $\left(\mathrm{H}_{2} \mathrm{SO}_{4}\right)$, HCL. Peralatan yang digunakan dalam penelitian terdiri atas peralatan untuk membuat tepung beras merah, tepung kacang kedelai, timbangan digital sebagai alat timbangan bahan, baskom sebagai wadah pencampuran bahan, kompor dan panci alat masak, cabinet dryer sebagai alat pengering bahan, blender untuk menghancurkan bahan, dan ayakan 80 mesh untuk menghasilkan tepung halus dan alat untuk analisis sifat fisik dan analisis kadar protein dengan labu kjeldahl, timbangan analitik, erlenmeyer, oven, tabung sentrifuse, gelas ukur, vibrator, dan spatula.

\section{Langkah-Langkah Penelitian}

Pembuatan MP-ASI dan daya terima produk dilakukan di Laboratorium Teknologi Jurusan Gizi Politeknik Kesehatan Makassar, sedangkan analisis karakteristik fisik dan karakteristik kimia dilakukan di Laboratorium Kimia SMK SMTI Makassar. Produk ini terdiri dari 3 formula yaitu formula 1 , formula 2 dan formula 3. Hal pertama yang dilakukan

\section{HASIL}

setelah pembuatan MP-ASI yaitu uji daya terima oleh panelis dengan menilai empat sapek, yaitu warna, aroma, rasa dan tekstur serta menggunakan skala hedonic yaitu sangat suka (4), suka (3), tidak suka (2) dan sangat tidak suka (1). Uji daya terima yang dilakukan oleh panelis nantinya akan menunjukkan produk MP-ASI lokal instan yang memiliki nilai daya terima tertinggi dan akan di analisis menggunakan uji anova. Setelah dilakukan uji daya terima oleh panelis, produk MP-ASI lokal instan yang memiliki nilai daya terima tertinggi selanjutnya akan di analisis karakteristik fisik dan kimia di laboratorium.

\section{Pengolahan dan analisis data}

Data yang telah dikumpulkan diolah menggunakan software Microsoft Excel 2010 dan menggunakan SPSS. Analisis data karakteristik fisik densitas kamba dibandingkan dengan standar karakteristik fisik densitas kamba yaitu 0,30-0,50 g/ml. Analisis karakteristik kimia pada MP-ASI dianalisis sesuai dengan prosedur. Data analisis yang telah didapatkan digunakan untuk menghitung nilai komposisi gizi pada bubuk instan lokal dan dibandingkan dengan standar yang telah ditetapkan oleh SNI.

Tabel 1

Persentase Daya Terima MP-ASI Instan Campuran

Tepung Beras Merah dan Tepung Kacang Kedelai

Berdasarkan Aspek Warna

\begin{tabular}{|c|c|c|c|c|c|c|c|c|c|c|c|}
\hline \multirow{3}{*}{$\mathrm{F}$} & \multicolumn{10}{|c|}{ Daya Terima Warna } & \multirow{3}{*}{$\mathrm{p}$} \\
\hline & \multicolumn{2}{|c|}{$\begin{array}{l}\text { Sangat } \\
\text { suka }\end{array}$} & \multicolumn{2}{|c|}{ Suka } & \multicolumn{2}{|c|}{$\begin{array}{l}\text { Tidak } \\
\text { suka }\end{array}$} & \multicolumn{2}{|c|}{$\begin{array}{c}\text { Sangat tidak } \\
\text { Suka }\end{array}$} & \multicolumn{2}{|c|}{ Total } & \\
\hline & $\mathrm{n}$ & $\%$ & $\mathrm{n}$ & $\%$ & $\mathrm{n}$ & $\%$ & $\mathrm{n}$ & $\%$ & $\mathrm{n}$ & $\%$ & \\
\hline $\mathrm{F} 1$ & 4 & 13 & 21 & 70 & 5 & 17 & 0 & 0 & 30 & 100 & \\
\hline $\mathrm{F} 2$ & 9 & 30 & 16 & 53 & 5 & 17 & 0 & 0 & 30 & 100 & 0,273 \\
\hline F3 & 4 & 13 & 19 & 64 & 6 & 20 & 1 & 3 & 30 & 100 & \\
\hline
\end{tabular}


Tabel 1 menunjukkan bahwa daya terima bubuk instan lokal dari aspek warna paling banyak disukai adalah F1 dan F2 sedangkan dengan nilai suka terendah yaitu F3. Berdasarkan aspek warna dari bubuk instan dengan campuran tepung beras merah dan tepung kacang kedelai pada F1 dan F2 sebanyak $83 \%$ panelis mengatakan suka sedangkan pada F3 sebanyak $77 \%$. Berdasarkan hasil uji anova menunjukkan tidak ada perbedaan daya terima terhadap aspek warna MP-ASI bubuk instan lokal campuran tepung beras merah dan tepung kacang kedelai dengan $(p=0,273)$.

Tabel 2

Persentase Daya Terima MP-ASI Instan Campuran

Tepung Beras Merah dan Tepung Kacang Kedelai

Berdasarkan Aspek Aroma

\begin{tabular}{cccccccccccc}
\hline \hline & \multicolumn{10}{c}{ Daya Terima Aroma } \\
F & $\begin{array}{c}\text { Sangat } \\
\text { suka }\end{array}$ & Suka & $\begin{array}{c}\text { Tidak } \\
\text { suka }\end{array}$ & $\begin{array}{c}\text { Sangat tidak } \\
\text { Suka }\end{array}$ & Total & \multirow{2}{*}{$\mathrm{P}$} \\
\cline { 2 - 11 } & $\mathrm{n}$ & $\%$ & $\mathrm{n}$ & $\%$ & $\mathrm{n}$ & $\%$ & $\mathrm{n}$ & $\%$ & $\mathrm{n}$ & $\%$ & \\
\hline F1 & 4 & 13 & 14 & 47 & 12 & 40 & 0 & 0 & 30 & 100 & \\
F2 & 5 & 17 & 22 & 73 & 3 & 10 & 0 & 0 & 30 & 100 & 0,187 \\
F3 & 8 & 27 & 12 & 40 & 9 & 30 & 1 & 3 & 30 & 100 & \\
\hline
\end{tabular}

Tabel 2 menunjukkan bahwa daya terima bubuk instan lokal dari aspek aroma paling banyak disukai adalah F2, lalu diikuti F3 kemudian dengan nilai suka terendah yaitu F1. Berdasarkan aspek aroma dari bubuk instan dengan campuran tepung beras merah dan tepung kacang kedelai pada F 2 sebanyak $90 \%$, dan F 3 sebanyak $67 \%$ panelis mengatakan suka sedangkan pada F 1 sebanyak $60 \%$. Berdasarkan hasil uji anova menunjukkan tidak ada perbedaan daya terima terhadap aspek aroma MP-ASI bubuk instan lokal campuran tepung beras merah dan tepung kacang kedelai $(p=0,187)$.

Tabel 3

Persentase Daya Terima MP-ASI Instan Campuran

Tepung Beras Merah dan Tepung Kacang Kedelai

Berdasarkan Aspek Tekstur

\begin{tabular}{|c|c|c|c|c|c|c|c|c|c|c|c|}
\hline \multirow{3}{*}{$\mathrm{F}$} & \multicolumn{10}{|c|}{ Daya Terima Tekstur } & \multirow{3}{*}{$\mathrm{p}$} \\
\hline & \multicolumn{2}{|c|}{$\begin{array}{l}\text { Sangat } \\
\text { suka }\end{array}$} & \multicolumn{2}{|c|}{ Suka } & \multicolumn{2}{|c|}{$\begin{array}{l}\text { Tidak } \\
\text { suka }\end{array}$} & \multicolumn{2}{|c|}{$\begin{array}{l}\text { Sangat tidak } \\
\text { Suka }\end{array}$} & \multicolumn{2}{|c|}{ Total } & \\
\hline & $\mathrm{n}$ & $\%$ & $\mathrm{n}$ & $\%$ & $\mathrm{n}$ & $\%$ & $\mathrm{n}$ & $\%$ & $\mathrm{n}$ & $\%$ & \\
\hline $\mathrm{F} 1$ & 1 & 3 & 11 & 37 & 13 & 44 & 5 & 16 & 30 & 100 & \\
\hline $\mathrm{F} 2$ & 0 & 0 & 9 & 30 & 15 & 50 & 6 & 20 & 30 & 100 & 0,802 \\
\hline F3 & 2 & 6 & 8 & 28 & 14 & 46 & 6 & 20 & 30 & 100 & \\
\hline
\end{tabular}

Tabel 3 menunjukkan bahwa daya

terima bubuk instan lokal dari aspek 
tekstur paling banyak disukai adalah $\mathrm{F} 1$, lalu diikuti F3 kemudian dengan nilai suka terendah yaitu F2. Berdasarkan aspek rasa dari bubuk instan dengan campuran tepung beras merah dan tepung kacang kedelai pada F 1 sebanyak 40\%, dan F 3 sebanyak $34 \%$ panelis mengatakan suka sedangkan pada F2 sebanyak 30\%. Berdasarkan hasil uji anova menunjukkan tidak ada perbedaan daya terima terhadap aspek tekstur MP-ASI bubuk instan lokal campuran tepung beras merah dan tepung kacang kedelai dengan $(p=0,802)$.

Tabel 4

Persentase Daya Terima Formula MP-ASI Instan Campuran

Tepung Beras Merah dan Tepung Kacang Kedelai

Berdasarkan Aspek Rasa

\begin{tabular}{|c|c|c|c|c|c|c|c|c|c|c|c|}
\hline \multirow{3}{*}{$\mathrm{F}$} & \multicolumn{10}{|c|}{ Daya Terima Rasa } & \multirow{3}{*}{$\mathrm{p}$} \\
\hline & \multicolumn{2}{|c|}{$\begin{array}{l}\text { Sangat } \\
\text { suka }\end{array}$} & \multicolumn{2}{|c|}{ Suka } & \multicolumn{2}{|c|}{$\begin{array}{l}\text { Tidak } \\
\text { suka }\end{array}$} & \multicolumn{2}{|c|}{$\begin{array}{c}\text { Sangat tidak } \\
\text { Suka }\end{array}$} & \multicolumn{2}{|c|}{ Total } & \\
\hline & $\mathrm{n}$ & $\%$ & $\mathrm{n}$ & $\%$ & $\mathrm{n}$ & $\%$ & $\mathrm{n}$ & $\%$ & $\mathrm{n}$ & $\%$ & \\
\hline F1 & 5 & 17 & 21 & 70 & 3 & 10 & 1 & 3 & 30 & 100 & \\
\hline $\mathrm{F} 2$ & 5 & 17 & 17 & 57 & 8 & 26 & 0 & 0 & 30 & 100 & 0,710 \\
\hline F3 & 5 & 17 & 18 & 60 & 6 & 20 & 1 & 3 & 30 & 100 & \\
\hline
\end{tabular}

Tabel 4 menunjukkan bahwa daya terima bubuk instan lokal dari aspek rasa paling banyak disukai adalah F1, lalu diikuti F3 kemudian dengan nilai suka terendah yaitu F2. Berdasarkan aspek rasa dari bubuk instan dengan campuran tepung beras merah dan tepung kacang kedelai pada F 1 sebanyak 87\%, dan F 3 sebanyak
$77 \%$ panelis mengatakan suka sedangkan pada F 2 sebanyak 74\%. Berdasarkan hasil uji anova menunjukkan tidak ada perbedaan daya terima terhadap aspek rasa MP-ASI bubuk instan lokal campuran tepung beras merah dan tepung kacang kedelai dengan $(p=0,710)$.

Tabel 5

Tingkat Kesukaan MP-ASI Instan dengan

Campuran Tepung Beras Merah dan Tepung Kacang Kedelai

\begin{tabular}{cc}
\hline \hline Formula Bubuk Instan & Skor Tingkat Kesukaan \\
\hline F1 & 329 \\
F2 & 336 \\
F3 & 326 \\
\hline
\end{tabular}

Tabel 5 menunjukkan bahwa MPASI bubuk instan dengan campuran tepung beras merah dan tepung kacang kedelai yang paling disukai yaitu $\mathrm{F} 2$ dengan nilai skor tingkat kesukaan paling tinggi yaitu 336 poin.
Karakteristik Fisik

Hasil penelitian dengan uji karakteristik fisik MP-ASI bubuk instan lokal dengan perlakuan uji densitas kamba yang dilakukan pada formula yang 
memiliki nilai tertinggi pada daya terima yaitu F2. Hasil uji densitas kamba didapatkan $0,80 \mathrm{~g} / \mathrm{ml}$.

\section{Karakteristik Kimia}

Formula MP-ASI instan yang dianalisis kandungan gizinya adalah formula yang memiliki nilai tertinggi pada tingkat kesukaan (tabel 12), yaitu F2. Kandungan gizi F2 diperoleh dari hasil proksimat yang kemudian dibandingkan dengan hasil pustaka. Perbandingan data hasil analisis dapat dilihat pada tabel 14 .

Tabel 6.

Kandungan Gizi MP-ASI (100 gram) Instan Lokal

\begin{tabular}{clccc}
\hline \hline \multirow{2}{*}{$\begin{array}{c}\text { Formulasi } \\
\text { Bubuk } \\
\text { Instan }\end{array}$} & Kandungan Gizi & \multicolumn{2}{c}{ Sumber } & \\
\cline { 3 - 4 } & & SNI & Proksimat & Keterangan \\
\hline \multirow{2}{*}{ F2 } & Protein (gr) & $8-22$ & 13,08 & Sesuai \\
& Lemak (gr) & $6-15$ & 19,23 & BelumSesuai \\
& Kadar Air (gr) & 4 & 5,71 & Belum Sesuai \\
& Kadar Abu (gr) & 3,5 & 2,56 & Belum Sesuai \\
\hline
\end{tabular}

Sumber : Data Primer Uji Proksimat, 2019 dan SNI, 2009

Berdasarkan tabel 14 diatas, dapat dilihat kadar protein sudah sesuai dengan standar SNI, sedangkan kadar air dan kadar abu belum sesuai dengan standar SNI.

\section{PEMBAHASAN}

Warna merupakan komponen yang pertama kali diamati dan dilihat oleh konsumen. Warna sangat penting untuk menentukan kualitas atau tingkat penerimaan suatu bahan pangan karena warna sangat penting pada suatu makanan sebagai daya tarik dan dapat membangkitkan selera makan. Suatu bahan meskipun dinilai enak dan teksturnya sangat baik, tetapi memiliki warna yang tidak menarik dapat menyebabkan tidak menariknya bahan tersebut (Winarno, 2004).

Berdasarkan hasil tabel 8 , terlihat bahwa penilaian kesukaan panelis terhadap aspek warna bubuk instan lokal yang dibuat dengan campuran tepung beras merah dan tepung kacang kedelai yang paling banyak disukai adalah F1 dan F2. Sedangkan penilaian terendah pada aspek warna yaitu F3. Hasil uji anova menunjukkan bahwa tidak ada perbedaan daya terima terhadap aspek warna produk MP-ASI bubuk instan lokal campuran tepung beras merah dan tepung kacang kedelai $(p=0,273)$. Hal ini dikarenakan perbedaan jumlah pemberian tepung beras merah dan tepung kacang kedelai hanya 5 gram dari setiap formula.

Penelitian ini tidak sejalan dengan Faris, dkk (2018) dengan judul kajian formulasi bubur bayi instan berbahan dasar tepung beras merah dan tepung ikan teri tinggi kalsium, yang dimana hasil penelitian tersebut menunjukkan tingginya persentase suka pada aspek warna pada formula yang diberikan tepung beras merah lebih banyak, sedangkan dalam penelitian ini persentase suka pada aspek warna dengan nilai tertinggi terdapat pada formula dengan komposisi tepung beras merah yang rendah.

Aroma adalah bau yang ditimbulkan oleh rangsangan kimia yang tercium oleh syaraf-syaraf olfaktori yang berada dalam rongga hidung (Winarno, 2004).

Berdasarkan hasil tabel 9, diperoleh keterangan bahwa penilaian kesukaan 
panelis terhadap aspek aroma bubuk instan lokal yang dibuat dengan campuran tepung beras merah dan tepung kacang kedelai yang paling banyak disukai adalah F2 kemudian F3 dan penilaian terendah pada F1. Hasil uji anova menunjukkan bahwa tidak ada perbedaan daya terima terhadap aspek warna produk MP-ASI bubuk instan lokal campuran tepung beras merah dan tepung kacang kedelai $(p=0,187)$, hal ini dikarenakan perbedaan jumlah pemberian tepung beras merah dan tepung kacang kedelai hanya 5 gram dari setiap formula.

Peneltian ini sejalan dengan penelitian yang dilakukan Gismawaty (2018) dengan judul formulasi bubur bayi instan dari tepung pregelatinisasi umbi uwi ungu dengan tepung kedelai sebagai alternatif makanan pendamping ASI, yang dimana hasil penelitian tersebut menunjukkan rendahnya nilai suka pada formula yang diberikan tepung kacang kedelai sebesar 20\% dikarenakan kedelai dapat memberikan aroma yang tidak disukai oleh panelis yang disebabkan oleh kerja enzim lipoksigenase yang terkandung dalam kedelai, senyawa volatile yang khas dari kedelai yaitu bau langu. Hal ini sesuai dengan Wulandari (2003), bahwa pada saat proses pengolahan kedelai memiliki hasil reaksi paling sedikit 8 senyawa volatile (mudah menguap) dimana senyawa yang paling banyak menghasilkan bau langu adalah etil-fenil-keton.

Tektur atau konsistensi makanan berkaitan dengan struktur makanan yang dirasakan saat didalam mulut. Tekstur makanan meliputi rasa daging, keempukan dan tingkat kekerasan makanan yang dapat dirasakan oleh indra pengecapan.

Berdasarkan hasil tabel 11 menunjukkan bahwa daya terima bubuk instan lokal dari aspek tekstur paling banyak disukai adalah F1, lalu diikuti F3 kemudian dengan nilai suka terendah yaitu F2. Berdasarkan hasil uji anova menunjukkan tidak ada perbedaan daya terima terhadap aspek tekstur MP-ASI bubuk instan lokal campuran tepung beras merah dan tepung kacang kedelai ( $p=$ 0,802 ), hal ini dikarenakan perbedaan jumlah pemberian tepung beras merah dan tepung kacang kedelai hanya 5 gram dari setiap formula.

Rasa makanan ditimbulkan oleh adanya rangsangan terhadap berbagai indra didalam tubuh manusia, terutama indra penglihatan, indra penciuman dan indra pengecapan.

Beberapa komponen yang berperan dalam penentuan rasa makanan adalah aroma, bumbu, tekstur, tingkat kematangan dan suhu makanan.

Berdasarkan hasil tabel 10, diperoleh keterangan bahwa penilaian kesukaan panelis terhadap aspek rasa bubuk instan lokal yang dibuat dengan campuran tepung beras merah dan tepung kacang kedelai yang paling banyak disukai adalah F1 kemudian F3 dan penilaian terendah pada F2. Hasil uji anova menunjukkan bahwa tidak ada perbedaan daya terima terhadap aspek warna produk MP-ASI bubuk instan lokal campuran tepung beras merah dan tepung kacang kedelai $(p=0,710)$, hal ini dikarenakan perbedaan jumlah pemberian tepung beras merah dan tepung kacang kedelai hanya 5 gram dari setiap formula.

Peneltian ini sejalan dengan yang dilakukan Gismawaty (2018) dengan judul formulasi bubur bayi instan dari tepung pregelatinisasi umbi uwi ungu dengan tepung kedelai sebagai alternatif makanan pendamping ASI, yang dimana hasilnya menyatakan penambahan tepung kacang kedelai yang tinggi dapat memberikan rasa yang tidak disukai oleh panelis yang disebabkan oleh kerja enzim lipsigenase dimana enzim ini dapat menimbulkan cita rasa langu (beany flavor) yang ada dalam biji kedelai. Begitupula dengan hasil analisis daya terima aspek rasa, dimana didaptkan persentase aspek rasa hanya $40 \%$ sedangkan yang tidak suka sebanyak 60. 


\section{Karakteristik Fisik}

Densitas kamba produk MP-ASI bubuk instan lokal yang didapatkan dalam penelitian ini yaitu $0,80 \mathrm{~g} / \mathrm{ml}$ dengan komposisi tepung beras merah 45 gr dan tepung kacang kedelai 35 gr serta tambahan susu full cream 15 gr dan gula pasir halus 5 gr. Hasil analisis yang didapatkan jika dibandingkan dengan standar bubuk intan pada umumnya belum sesuai yang dimana hasil densitas kamba produk lebih tinggi dibandingkan standar umum.

Penelitian ini tidak sejalan dengan penelitian Hesti, Dian dan Dwi (2013) yang dimana menyatakan bahwa dengan adanya perendaman, maka densitas kamba akan semakin menurun karena kadar air meningkat. Sedangkan dalam penelitian ini, bahan yang akan dijadikan tepung sebelumnya telah dilakukan perendaman, tetapi hasil densitas kamba yang dihasilkan tinggi.

\section{Karakteristik Kimia}

Protein merupakan zat gizi yang sangat penting untuk tubuh kita karena protein tersebut memiliki fungsi sebagai zat pebangun. Zat pembangun merupakan suatu zat sebagai pembentuk jaringan baru dan sangat penting dalam pertumbuhan (Winarno, 2004)

Kadar protein pada produk MP-ASI bubuk instan lokal yang dihasilkan dari penelitian ini adalah 13,08 gr, dengan komposisi tepung beras merah 45 gr dan tepung kacang kedelai 35 gr serta tambahan susu full cream 15 gr dan gula pasir halus 5 gr. Hasil analisis yang didapatkan jika dibandingkan dengan standar SNI telah sesuai.

Penelitian ini sejalan dengan penelitian Gismawaty (2018) dengan judul formulasi bubur bayi instan dari tepung pregelatinisasi umbi uwi ungu dengan tepung kedelai sebagai alternatif makanan pendamping ASI, yang dimana hasil penelitian yang menunjukkan protein bubur bayi instan yang paling tinggi yaitu pada perlakuan penggunaan $20 \%$ tepung kedelai nilainya sebesar $15,37 \%$, Protein sangat berpengaruh terhadap pertumbuhan dan pemeliharaan sel bayi. Tingginya nilai pada perlakuan $20 \%$ tepung kedelai dan hasil berbeda nyata sampel dipengaruhi dari tingginya kandungan protein yang dikandung oleh tepung kedelai dimana tepung kedelai memiliki kandungan protein sebesar $36.00 \mathrm{~g}$ sedangkan tepung uwi sebesar 6,79 g, sehingga semakin besar penambahan tepung kedelai dalam formulasi bubur bayi instan maka semakin besar pula kandungan protein pada bubur bayi instan yang dihasilkan.

Kadar lemak pada produk MP-ASI bubuk instan lokal pada penelitian ini adalah 19,23 gr dengan komposisi tepung beras merah 45 gr dan tepung kacang kedelai 35 gr serta tambahan susu full cream 15 gr dan gula pasir halus 5 gr. Hasil analisis yang didapatkan jika dibandingkan dengan standar SNI belum sesuai yang dimana pada hasil analisis dihasilkan 19,23 gr sangat tinggi dibanding standar SNI yaitu 6-15 gr.

Penelitian ini sejalan dengan penelitian Gismawaty (2018) dengan judul formulasi bubur bayi instan dari tepung pregelatinisasi umbi uwi ungu dengan tepung kedelai sebagai alternatif makanan pendamping ASI, yang dimana hasil penelitian yang menunjukkan lemak pangan bubur bayi instan yang paling tinggi yaitu pada perlakuan penggunaan $20 \%$ tepung kedelai nilainya sebesar $2,57 \%$ dan yang paling rendah yaitu pada perlakuan penggunaan $0 \%$ tepung kedelai nilainya sebesar $0,50 \%$. Kandungan lemak didapatkan dari bahan baku yang digunakan pada pembuatan bubur bayi instan yaitu tepung kedelai, dimana kedelai mengandung asam lemak tidak jenuh ganda yang terdapat dalam kedelai, yaitu asam linoleat dan linolenat yang sangat dibutuhkan dalam pertumbuhan bayi. 
Perbedaan kandungan lemak dipengaruhi oleh jumlah penambahan tepung kedelai yang digunakan pada setiap perlakuan. Kandungan lemak pada tepung kedelai yaitu $19.00 \mathrm{~g}$ dan tepung uwi $0,2 \mathrm{~g}$, sehingga semakin besar penambahan tepung kedelai maka semakin tinggi pula kandungan lemak yang dihasilkan pada bubur instan.

Kadar air produk MP-ASI bubuk instan lokal yang didapatkan dalam penelitian ini yaitu $5,71 \%$ dengan komposisi gr dengan komposisi tepung beras merah 45 gr dan tepung kacang kedelai 35 gr serta tambahan susu full cream 15 gr dan gula pasir halus 5 gr. Hasil analisis yang didapatkan jika dibandingkan dengan standar SNI belum sesuai yang dimana pada hasil analisis dihasilkan 5,71\% sangat tinggi dibanding standar SNI yaitu 4.

Kadar abu mengindikasikan kandungan senyawa anorganik dalam bahan pangan, semakin tinggi kadar abu maka semakin tinggi kandungan mineral dalam suatu bahan.

Kadar abu produk MP-ASI bubuk instan lokal yang didapatkan dalam penelitian ini yaitu $2,56 \%$ dengan komposisi gr dengan komposisi tepung beras merah 45 gr dan tepung kacang kedelai 35 gr serta tambahan susu full cream 15 gr dan gula pasir halus 5 gr. Hasil analisis yang didapatkan jika dibandingkan dengan standar SNI belum sesuai yang dimana pada hasil analisis dihasilkan 2,56\% masih dibawah jika dibanding standar SNI yaitu 3,5, sedangkan dari hasil pustaka tidak ada kadar abu yang ditemukan sehingga tidak dapat dibandingkan dengan hasil pustaka.

Penelitian ini sejalan dengan Gismawaty (2018) yang dimana hasil analisa kadar abu bubur bayi instan menunjukkan kadar abu bubur bayi instan yang paling tinggi yaitu pada perlakuan penggunaan $20 \%$ tepung kedelai nilainya sebesar $3,48 \%$ dan yang paling rendah yaitu pada perlakuan penggunaan $10 \%$ tepung kedelai nilainya sebesar $2,31 \%$. Berdasarkan hasil analisa kadar abu yang dihasilkan menunjukkan bahwa semakin tinggi kosentrasi tepung kedelai dalam bubur bayi instan, semakin tinggi pula kadar abu yang dihasilkan. Hal ini disebakan oleh banyaknya kandungan mineral dari tepung kedelai yaitu berupa $\mathrm{K}$, Fe, Zn, dan $\mathrm{P}$. yang dihasilkan menunjukkan bahwa semakin tinggi kosentrasi tepung kedelai dalam bubur bayi instan, semakin tinggi pula kadar abu yang dihasilkan. Hal ini disebakan oleh banyaknya kandungan mineral dari tepung kedelai yaitu berupa $\mathrm{K}, \mathrm{Fe}, \mathrm{Zn}$, dan $\mathrm{P}$.

\section{KESIMPULAN}

Daya terima MP-ASI bubuk instan lokal dari aspek warna yang paling disukai yaitu $\mathrm{F} 1$ dan $\mathrm{F} 2$, aspek aroma yang paling disukai yaitu $\mathrm{F} 2$, aspek rasa yang paling disukai yaitu F1 dan aspek tekstur yang paling disukai yaitu F1. Tingkat kesukaan yang mendpatkan nilai tertinggi adalah F2. Karakteristik fisik densitas kamba F2 MPASI bubuk instan yang telah dianalisis didapatkan $0,80 \mathrm{~g} / \mathrm{ml}$ yang dimana tidak sesuai dengan standar densitas kamba pada umumnya $(0,30-0,50 \mathrm{~g} / \mathrm{ml})$. Kandungan gizi F2 MP-ASI bubuk instan dalam 100 gr yang telah dianalisis didapatkan protein 13,08 gr dan telah sesuai dengan standar SNI, sedangkan lemak 19,23 gr, kadar air 5,71 gr dan kadar abu 2,56 belum sesuai dengan standar SNI.

\section{SARAN}

$$
\text { Bagi peneliti selanjutnya }
$$
disarankan agar dapat melakukan uji analisis zat gizi mikro pada produk MPASI bubuk instan, mencari formula yang tepat agar kadar lemak, kadar air dan densitas kamba pada produk MP-ASI bubuk instan agar dapat sesuai dengan standar dan disarankan mampu melakukan uji daya terima atau uji comstok pada bayi untuk melihat tingkat kesukaan. 


\section{DAFTAR PUSTAKA}

Badan Standardisasi Nasional. Standardisasi Nasional Indonesia SNI. (2005). Makanan Pendamping ASI Bubuk Instan.

Faris ,Tamrin dan Sri Rejeki. 2018. Kajian Formulasi Bubur Bayi Instan Berbahan Dasar Tepung Beras Merah (Oryza Nivara) Dan Tepung Ikan Teri (Stolephorus Sp) Tinggi Kalsium. Jurusan Ilmu dan Teknologi Pangan, Fakultas Pertanian, Universitas Halu Oleo, Kendari

Gismaswaty, L. 2018. Formulasi Bubur Bayi Instan Dari Tepung Pregelatinisasi Umbi Uwi Ungu (Dioscorea Alata L.) Dengan Tepung Kedelai (Glycine Max L. Merr) Sebagai Alternatif Makanan Pendamping Air Susu Ibu.Skripsi Program Studi Ilmu Dan Teknologi Pangan Departemen Teknologi Pertanian Fakultas Pertanian Universitas Hasanuddin Makassar

Hesti AP, Dian RA dan Dwi I. 2013. Karakteristik Sifat Fisik dan Kimia Tepung Kacang Merah (Phaseolus vulgaris L) dengan Beberapa Perlakuan Pendahuluan. Jurusan Teknologi Hasil Pertania Universitas Sebelas Maret. Jurnal Teknosains Pangan. Vol 2 No 1. Diakses 26 Mei 2019

Kementerian Kesehatan RI. (2012). Pedoman Kegiatan Gizi Dalam Penanggulangan Bencana. Jakarta. Kementerian Kesehatan RI. (2016). Situasi Balita Pendek. Jakarta.

Kementerian Kesehatan RI. (2017). Pemantauan Status Gizi. Direktorat Gizi Masyarakat Direktorat Jenderal Kesehatan Masyarakat. Jakarta.

Ramayulis R, Triyani Kresnawan, Sri Iwaningsih, Dkk. (2018). Stop Stunting dengan Konseling Gizi. Persatuan Ahli Gizi Indonesia. Jakarta Timur. Penebar Plus.

Warsino dan Dahana Kres. (2010). Meraup Untung Dari Olahan Kedelai. Jakarta. Agro media Pustaka.

Winarno, F.G.2004. Kimia Pangan dan Gizi. Jakarta: Gramedia. Pengolahan Universitas Gadjah Mada. Yogyakarta 